\title{
Urban Greening and the UHI: Seasonal Trade-offs in Heating and Cooling Energy Consumption in Manchester, UK
}

\author{
Cynthia Pamela Skelhorn', Sarah Lindley², Geoff Levermore ${ }^{3}$ \\ ${ }^{1}$ Qatar Green Building Council, PO Box 5825, Doha, Qatar, cskelhorn@qf.org.qa \\ ${ }^{2}$ School of Education, Environment and Development, University of Manchester, UK \\ sarah.lindley@manchester.ac.uk \\ ${ }^{3}$ School of Mechanical, Aerospace, and Civil Engineering, University of Manchester, UK, \\ geoff.levermore@manchester.ac.uk
}

Dated: 15 June 2015

\section{Introduction}

In Northwest England, UK, climate change projections estimate that mean summer air temperature will rise by approximately $3.7^{\circ} \mathrm{C}$ by the 2080's (medium emissions scenario, $50 \%$ probability level, $1961-1990$ baseline). Previous research on the Urban Heat Island Intensity (UHII) in Manchester and Greater Manchester (Cheung 2011), found that the UHII can reach $8 \mathrm{~K}$ and is also increasing over time.

For urban areas, increasing the proportion of greenspace is an adaptation strategy that is often suggested. While numerous studies have investigated the cooling effect of greenspace in terms of both air and surface temperatures, few studies have further investigated the links to building energy demand.

This research presents an interdisciplinary approach to model fine-scale microclimate changes due to greenspace additions, using the results to develop customised weather files for modelling building energy consumption in commercial buildings. This research builds on previous work presented on the summer microclimate and building energy changes presented at the Third International Conference on Countermeasures to the Urban Heat Island (IC2UHI3) (Skelhorn et al. 2014b).

\section{Methods}

Considering the large number of variables that influence microclimate interactions between buildings and greenspace, such as its location in the UHI, the building geometry, and surface characteristics surrounding it, coupled with a similar variability in energy usage data for different buildings (age, size, construction materials, HVAC characteristics and occupancy rates), modelling was determined to be a useful approach for assessing changes in building energy consumption due to different types and arrangements of greenspace.

Modelling occurred in two stages: microclimate modelling to determine changes in air temperature, relative humidity, and wind due to increases in greenspace; and building energy modelling, utilizing the microclimate results to inform weather file inputs and the related impacts to building energy.

In addition to modelling, this paper utilises analysis of the UHII in the City of Manchester and Greater Manchester local authority in the northwest of England, UK. Research by Cheung (2011) collected air temperature data using iButton temperature sensors that were attached to lampposts. The air temperature data were useful for: 1) calibrating and validating the microclimate element of the modelling; and 2) determining the seasonal daytime and nighttime averages of the Manchester UHII (Skelhorn et al. 2014b).

\subsection{Urban Microclimate Modelling}

The modelling process began by selecting a suitable energy balance model. While many models have been developed for fine-scale investigation of urban canyons and neighbourhoods (Ali-Toudert and Mayer 2006; Baklanov et al. 2009), most are either slab or single-layer and did not include canopy details. One model which met the objectives of the microclimate modelling is the model ENVI-met, (Bruse and Fleer 1998; Bruse 2004). It is specifically designed for modelling surface-plant-air interactions in the urban environment. Full reasoning for this selection, its benefits and limitations, are discussed in Skelhorn et al. (2014).

The Manchester CBD was selected for its mix of medium and tall retail and commercial buildings combined with low tree cover and relatively high surface temperatures. This area was selected as being most lacking in greenspace, and therefore, a useful modelling study for greenspace additions. Figure 1 shows an overhead view of the Manchester CBD area from Google Earth that was used for digitizing the area in ENVI-met. Percentages of buildings and tree canopy for the areas were estimated in ArcMap 9.3, while total greenspace for the area was estimated using colour pixel analysis in Adobe Photoshop®CS2.

Building and greenspace percentages for Manchester CBD are estimated as: 
- $\quad$ Buildings - 36\%;

- Greenspace - 3\% (tree canopy cover is $1 \%$ of this);

- $\quad$ Roads, Pavements, Parking - 61\%.

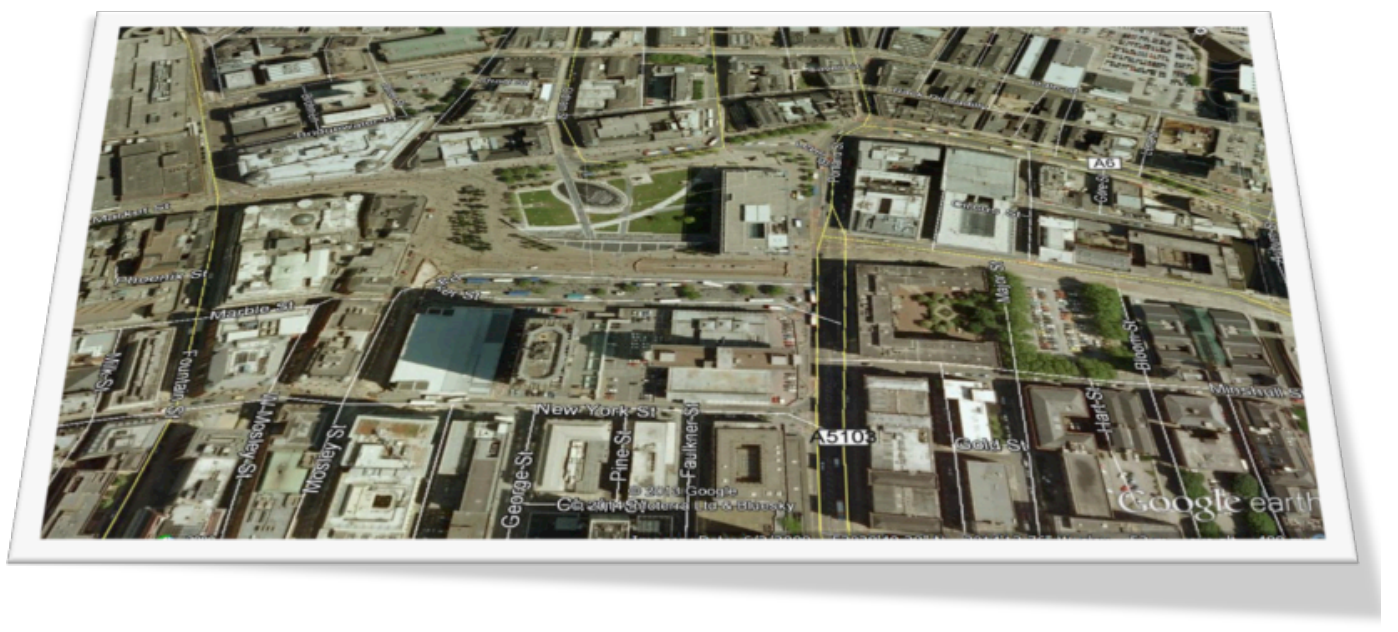

Figure 1 - Google Image of City Centre Study Area

Areas to be modelled are input on a rectangular grid which can range from small areas less than $20 \times 20$ cells up to a maximum of $250 \times 250$ cells, with each cell having a resolution of $0.5 \mathrm{~m}$ up to $10 \mathrm{~m}$. Because larger model areas and/or higher resolution models require significantly longer running times, it was important to select a model size and resolution that was manageable, which was a resolution of $4 \mathrm{~m}$ for this research.

\subsection{Building Energy Modelling}

In the UK, AECOM oversees a Building Energy Calculation Software Approval Scheme on behalf of Communities and Local Government (CLG) (Lim 2009). Only two software programmes, TAS and Virtual Environment (VE) by IES, are on the approved list for Dynamic Simulation Modelling (DSM), a method that can model the thermal dynamic response of buildings and demonstrate compliance with Part $L$ of the Building Regulations (HM Government 2010).

IES-VE was chosen for a number of advantages. These include a user-friendly interface as well as low cost to students and academic researchers. Hourly weather data required for simulations are available for Manchester from CIBSE and custom weather files can be created for testing the effects of changing weather patterns. Importantly, for this research, the SunCast module is included for determining the effects of shading due to elements on or around the building.

\subsubsection{Building Models}

The simulation focuses on two (out of four) types of office buildings identified in the UK by BRE and CIBSE (CIBSE 2000). Those selected are:

- Air-conditioned, standard; and

- $\quad$ Air-conditioned, prestige.

A total of three buildings were examined:

- Two versions of the standard building, one shallow-plan three-storey, and one shallow-plan ten-storey; and

- One prestige, deep-plan three-storey.

The buildings were sketched in IES-VE. Table 1 provides the building details while Figures 2, 3, and 4 show the three buildings as sketched in IES-VE (Skelhorn et al. 2014b). All buildings were modelled as a General Office with $20 \%$ glazing and building constructions applied were to the 2002 Building Regulations for England and Wales (HM Government 2002). Key thermal template settings (ibid.) were:

- Timing - Office 8:00-6:00;

- Cooling Temperature $-23.0^{\circ} \mathrm{C}$;

- Heating Temperature $-19.0^{\circ} \mathrm{C}$;

- $\mathrm{RH}-70 \%$ maximum;

- $\mathrm{ACH}-0.250$ Infiltration; and

- Internal Gains - Fluorescent lighting, $12 \mathrm{~W} / \mathrm{m}^{2}$; Occupancy 14 m²/person; Equipment, 12 W/m².

Table 1 - Building Types and Descriptions (Skelhorn et al. 2014b)

\begin{tabular}{|l|l|l|l|}
\hline $\begin{array}{l}\text { Building } \\
\text { Designation }\end{array}$ & $\begin{array}{l}\text { Plan } \\
\text { Type }\end{array}$ & Floor Area and Layout & Height \\
\hline
\end{tabular}




\begin{tabular}{|l|l|l|r|}
\hline A & Shallow & $972 \mathrm{~m}^{2}-9(6 \mathrm{~m} \times 6 \mathrm{~m})$ rooms per floor & 3 Floors \\
\hline B & Shallow & $3240 \mathrm{~m}^{2}-$ same layout as building A & 10 Floors \\
\hline C & Deep & $\begin{array}{l}5418 \mathrm{~m}^{2}-84(3 \mathrm{~m} \times 3 \mathrm{~m}) \text { rooms, } 4 \text { central open plan areas } \\
(10 \mathrm{~m} \times 15 \mathrm{~m}), 18 \text { larger offices }(5 \mathrm{~m} \times 5 \mathrm{~m})\end{array}$ & 3 Floors \\
\hline
\end{tabular}

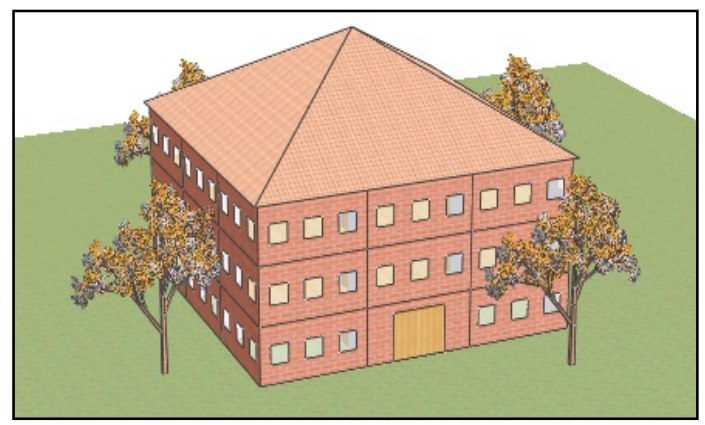

Figure 2 - Building A - Three-Storey Shallow Plan

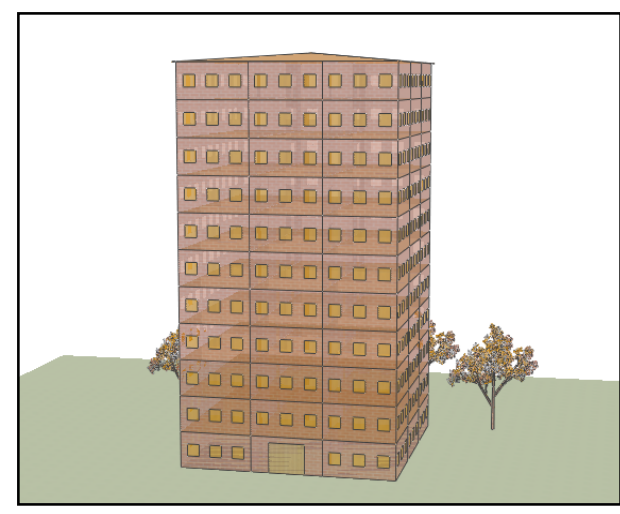

Figure 3 - Building B - Ten-Storey Shallow Plan

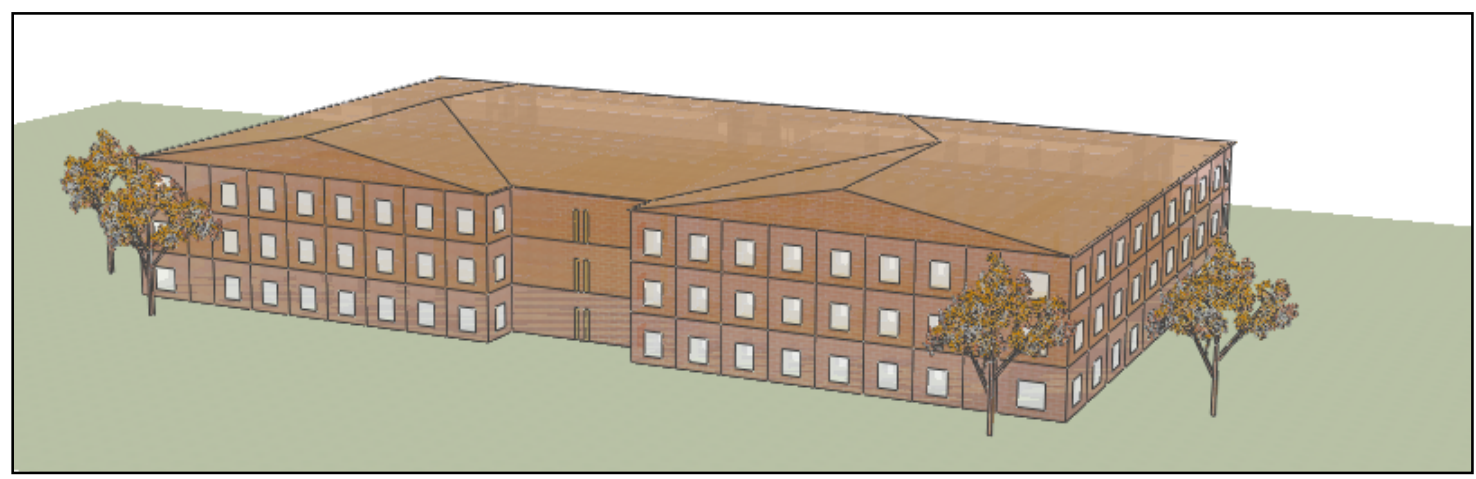

Figure 4 - Building C - Three-Storey Deep Plan

\subsubsection{Summer Energy Scenarios}

Each building was first modelled without tree shading, using the July Test Reference Year (TRY) weather data for Manchester Airport. Trees of approximately $10 \mathrm{~m}$ were selected as the shading element given that mature trees were found to have the most effect in the microclimate modelling (Skelhorn et al. 2014b). This base case was then compared with the following:

- Shade - North Four trees added as Topographic Shade, shading approximately $20 \%$ of the North side of the building; and South - Four trees added as Topographic Shade, shading $20 \%$ of the South side of the building;

- Urb_UHI - To simulate each building's energy increase due to the UHI (i.e., a building placed in urban conditions), a new weather file (UHI+6) was created in IES-VE. In the UHI+6 file, daytime temperatures were increased by $1.5{ }^{\circ} \mathrm{C}$, and nighttime by $3{ }^{\circ} \mathrm{C}$. These values are based on Manchester research (Cheung 2011) showing average summer daytime/nighttime UHII. Also, in the TRY dataset, nearly two full days in July (16th-18th) are clear, calm and warm days, which are conditions for an intense UHI, so temperatures were increased strongly, $+3{ }^{\circ} \mathrm{C}$ for daytime and $+{ }^{\circ} 6$ for nighttime;

- Urb_UHI_green - To test the effect of greening (shading plus reduced UHII peak hours), a new weather file (UHI+6_green) was created based on the TRY_UHI+6 file. The UHII on the peak days (16th-18 ${ }^{\text {th }}$ July) was reduced by $1{ }^{\circ} \mathrm{C}$, resulting in $+2{ }^{\circ} \mathrm{C}$ for daytime and $+5{ }^{\circ} \mathrm{C}$ for nighttime. This reduction in UHII due to greening is based on the negative summer correlation between UHII and area of tree canopy from an analysis as part of a Manchester thesis (Skelhorn 2013). The regression equation indicates a potential reduction of 10 cooling degree hours for each $5 \%$ increase in greenspace. These results are scaled up, allowing for a total of 40 cooling degree hours due to the $20 \%$ shading around the shallow-plan threestorey building. 


\subsubsection{Winter Energy Scenarios}

For the winter investigation, a model using the December TRY weather data and a model under UHI conditions are compared. In winter, the daytime $\mathrm{UHI}$ average is $1.6^{\circ} \mathrm{C}$, while the nocturnal $\mathrm{UHI}$ is $3.1^{\circ} \mathrm{C}$. Under clear and calm, peak UHI, conditions, the UHI daytime mean is $2.0^{\circ} \mathrm{C}$ and nighttime mean is $6.0^{\circ} \mathrm{C}$. The clear and calm conditions (defined as $<3 \mathrm{~m} / \mathrm{s}$ wind speed and $<2$ oktas of cloud cover) occurred on portions of several days $\left(7^{\text {th }}\right.$ $9^{\text {th }}, 12^{\text {th }}$ and $14^{\text {th }}$ December), totalling 39 hours in the month.

Analysis of air temperature data collected with iButtons did not find any correlations between area of tree canopy and the air temperature indices investigated for the month of December. Therefore, the modelling assumes a neutral air temperature effect from greening for winter months.

\section{Results}

\subsection{Summer Building Energy Modelling}

Results from the summer energy modelling (Table 2) show a maximum of $1.6 \%$ reduction in chiller energy as a combined result of four trees shading the south side of the building and the reduction of UHII peak hours on a shallow plan three-storey building. Total reductions for this same building with the combined effects of 4 trees on the north and 4 trees on the south are estimated at $2.7 \%$.

Table 2 - Summer Results, Chiller Energy Usage (MWh) (Extract from Skelhorn et al. 2014b)

\begin{tabular}{|c|c|c|c|c|c|c|c|c|}
\hline \multirow[t]{2}{*}{ Building } & \multirow[t]{2}{*}{$\begin{array}{l}\text { Tree } \\
\text { Location }\end{array}$} & $\begin{array}{l}\text { Base } \\
\text { Energy, } \\
\text { Chillers }\end{array}$ & \multicolumn{2}{|l|}{ Shade } & \multicolumn{2}{|l|}{ Urb_UHI } & \multicolumn{2}{|c|}{ Urb_UHI_green } \\
\hline & & $\begin{array}{l}\text { Amount } \\
\text { (MWh) }\end{array}$ & $\begin{array}{l}\text { Amount } \\
\text { (MWh) }\end{array}$ & $\begin{array}{l}\% \\
\text { Change }\end{array}$ & $\begin{array}{l}\text { Amount } \\
\text { (MWh) }\end{array}$ & $\begin{array}{l}\text { \% Change } \\
\text { (from } \\
\text { Base) }\end{array}$ & $\begin{array}{l}\text { Amount } \\
\text { (MWh) }\end{array}$ & $\begin{array}{l}\text { \% Change } \\
\text { (from } \\
\text { Urb UHI) }\end{array}$ \\
\hline \multirow[t]{2}{*}{ A } & North & \multirow{2}{*}{3.6168} & 3.5833 & $-0.9 \%$ & \multirow{2}{*}{4.0555} & \multirow{2}{*}{$12.1 \%$} & 4.0126 & $-1.1 \%$ \\
\hline & South & & 3.5628 & $-1.5 \%$ & & & 3.9921 & $-1.6 \%$ \\
\hline \multirow[t]{2}{*}{$B$} & North & \multirow{2}{*}{11.2775} & 11.2494 & $-0.3 \%$ & \multirow{2}{*}{12.6552} & \multirow{2}{*}{$12.2 \%$} & 12.6001 & $-0.4 \%$ \\
\hline & South & & 11.2380 & $-0.4 \%$ & & & 11.209 & $-0.6 \%$ \\
\hline \multirow[t]{2}{*}{$\mathrm{C}$} & North & \multirow{2}{*}{22.5894} & 22.4979 & $-0.4 \%$ & \multirow{2}{*}{24.8123} & \multirow{2}{*}{$9.8 \%$} & 24.677 & $-0.6 \%$ \\
\hline & South & & 22.4652 & $-0.6 \%$ & & & 24.6441 & $-0.7 \%$ \\
\hline
\end{tabular}

The percentage savings is reduced for a deep plan building $(0.7 \%$ for four trees on the south side and a reduction in number of UHII peak hours), primarily due to the fact that the same four trees in this scenario will not be shading an equivalent surface area (only $10 \%$ of the building's surface in this model). However, if the model had achieved the $20 \%$ shading of the shallow-plan building and assuming a linear relationship, this would lead to $1.4 \%$ savings, a slightly lower reduction than achieved in the shallow plan building. This is reasonable due to the larger internal building volume for a deep-plan building that would be unaffected by shading measures.

Savings would likely be greater in air-conditioned buildings that are occupied during the nighttime, when UHII is greatest. As these buildings are modelled as office buildings, the air conditioning is switched off at night, potentially masking the potential savings for buildings that are occupied at this time.

\subsubsection{Summer Carbon Emissions}

Table 3 shows the changes in carbon emissions (for the set of buildings with $20 \%$ glazing) due to the average summer $\mathrm{UHI}\left(+1.5{ }^{\circ} \mathrm{C}\right.$ daytime and $+3.0^{\circ} \mathrm{C}$ nighttime). The results show the greatest increase for the 10 -storey shallow plan building and the least increase for the deep plan building. While the deep plan building shows a higher overall usage and higher usage per square metre, the energy consumption increased by a lower percentage than buildings $\mathrm{A}$ and $\mathrm{B}$ under the $\mathrm{UHI}$ conditions.

Table 3 - Changes in Summer (July) Carbon Emissions due to UHI

\begin{tabular}{||l|r|r|r||}
\hline Building & Chiller CE Base (Electricity, $\mathrm{kg} \mathrm{CO}_{2}$ ) & \multicolumn{2}{|c|}{ Chiller CE Urb_UHI } \\
\hline & & Amount & $\%$ Change \\
\hline A & 6714 & 7020 & $4.6 \%$ \\
\hline B & 20323 & 21284 & $4.7 \%$ \\
\hline C & 46517 & 48068 & $3.3 \%$ \\
\hline
\end{tabular}


If also considering the direct reduction in $\mathrm{CO}_{2}$ emissions due to the carbon sequestered by each tree, the carbon savings due to tree planting in urban areas is marginally higher. Akbari (2002) estimated that each urban tree can reduce an average of 4.6-11.4 $\mathrm{kg} \mathrm{CO}$ per year (with older trees sequestering more carbon). This leads to an estimate of at least $1 \mathrm{~kg} \mathrm{CO}$ per tree for the month of July, considering that the most tree growth in the UK is during spring and summer. With four trees around each building, the reduction is $4 \mathrm{~kg} \mathrm{CO}_{2}$ for July

\subsection{Winter Building Energy Modelling}

In comparing the energy changes for winter (Table 4) large percentage reductions in boiler energy are found for all buildings located in the urban area under UHI conditions, as compared to the base case (suburban) location. However, while chiller usage is smaller in absolute terms, this shows substantial increases for the urban location. This is explained by the fact that, depending on the building construction and thermal profile, chillers may be required in winter to offset internal gains.

Table 4 - Winter (December) Table of Results, Boiler and Chiller Energy Usage

\begin{tabular}{||l|r|r|r|r|r|r||}
\hline \hline Building & \multicolumn{1}{|c|}{$\begin{array}{c}\text { Base Energy, } \\
\text { Boilers }\end{array}$} & \multicolumn{2}{|c|}{$\begin{array}{c}\text { Boiler Energy with Avg } \\
\text { UHI }\end{array}$} & \multicolumn{2}{c|}{$\begin{array}{c}\text { Base Energy, } \\
\text { Chillers }\end{array}$} & \multicolumn{2}{c|}{$\begin{array}{c}\text { Chiller Energy with Avg } \\
\text { UHI }\end{array}$} \\
\hline & MWh & \multicolumn{1}{|c||}{ MWh } & \% Change & MWh & MWh & $\%$ Change \\
\hline A & 1.6262 & 0.726 & $-55.4 \%$ & 0.6631 & 0.8734 & $31.7 \%$ \\
\hline B & 4.4010 & 1.7875 & $-59.4 \%$ & 1.1761 & 1.8536 & $57.6 \%$ \\
\hline C & 2.3309 & 0.8453 & $-63.7 \%$ & 7.7157 & 9.824 & $27.3 \%$ \\
\hline
\end{tabular}

\subsubsection{Winter Carbon Emissions}

Following on from the changes to boiler and chiller energy discussed in the previous section, Table 5 summarises the changes in carbon emissions from these same scenarios. This was important to investigate as it is often argued that the benefit of a winter UHI is more important for energy savings than the detriment of a summer UHI. While it might be true that, in absolute terms, the reduction in boiler energy outweighs the increase in chiller energy, the results shown in Table 5 indicate only a very slight advantage to carbon emissions when investigating the trade-offs in boiler and chiller energy for December. The results show that carbon emissions due to chiller usage are far higher than that for boilers. Building $A$, for example, only has carbon emissions of $322 \mathrm{~kg}$ (suburban), and although reduced to $144 \mathrm{~kg}$ for the average UHI conditions, the relatively small amount of chiller energy leads to $4652 \mathrm{~kg} \mathrm{CO}$ for the suburban and increases to $4799 \mathrm{~kg}$ for the urban UHI.

While it could be argued that a UK building is unlikely to use chiller energy in winter, the same comparison could also be made for summer to winter trade-offs. Even if chillers were completely turned off in winter, the case is more apparent for carbon emissions due to summer air conditioning usage. On balance, in terms of carbon emissions, any increase in summer air conditioning will outweigh the reductions in winter heating for buildings using gas boilers for heating and electricity for air conditioning.

Table 5 - Changes in Winter (December) Carbon Emissions

\begin{tabular}{|c|c|c|c|c|c|c|c|c|c|}
\hline Building & $\begin{array}{l}\text { Boiler CE (Natural } \\
\left.\text { Gas, kg CO } \mathrm{CO}_{2}\right)\end{array}$ & Boiler & $\begin{array}{l}\text { E with Avg } \\
\text { UHI }\end{array}$ & $\begin{array}{c}\text { Chiller CE } \\
\left.\text { (Electricity, kg CO}{ }_{2}\right)\end{array}$ & Chiller & $\begin{array}{l}\text { with Avg } \\
\text { II }\end{array}$ & $\begin{array}{l}\text { Total System CE } \\
\left(\text { Electricity, } \mathrm{kg} \mathrm{CO}_{2}\right)\end{array}$ & Total S & $\begin{array}{l}\text { em CE with } \\
\text { UHI }\end{array}$ \\
\hline & & kg & $\%$ Change & & kg & $\begin{array}{c}\% \\
\text { Change }\end{array}$ & kg & kg & $\%$ Change \\
\hline$A$ & 322 & 144 & $-55.3 \%$ & 4652 & 4799 & $3.2 \%$ & 4974 & 4943 & $-0.6 \%$ \\
\hline$B$ & 871 & 354 & $-59.4 \%$ & 13272 & 13745 & $3.6 \%$ & 14144 & 14099 & $-0.3 \%$ \\
\hline $\mathrm{C}$ & 462 & 167 & $-63.9 \%$ & 36136 & 37607 & $4.1 \%$ & 36597 & 37775 & $3.2 \%$ \\
\hline
\end{tabular}

\section{Conclusions}

While it may appear that the benefits of a winter UHI far outweigh the summer detriment, it is worthwhile to further examine some of the causes for the large differences estimated here. One explanation is possibly in the methods used to develop the summer and winter UHI weather files. During the summer, the UHI analysis is more weighted to the daytime average of $1.5^{\circ} \mathrm{C}$ because sunrise is typically around 5 am and sunset around 9 $\mathrm{pm}$ (16 daytime hours). During the winter, the $\mathrm{UHI}$ analysis is weighted toward the nighttime average of $3.1^{\circ} \mathrm{C}$ because sunset is, on average, at $4 \mathrm{pm}$, and sunrise is not until 8 am (16 nighttime hours). In reality, this 
daytime/nighttime differentiation is likely to be less straightforward and more of a gradual increase or decrease in temperature differences than estimated here.

Also, the exact causes of a higher winter UHI require further investigation. Undoubtedly, some portion of the $\mathrm{UHI}$ is due to greater thermal mass and heat storage/release in urban areas, but it might be argued that an anthropogenic component enhances this (Smith et al., 2009). Another cause may be warm air leakage due to poorly sealed buildings, which would represent an excess of boiler energy in any initial calculation of energy consumption.

Using mature trees of $10 \mathrm{~m}$ height, the building energy modelling estimated a reduction of $2.7 \%$ in July chiller energy due to the combination of reduced UHI peak hours and eight additional trees (four on the north side and four on the south side) surrounding a three-storey shallow plan building, with savings increasing to $4.8 \%$ under a three-day period of peak UHI conditions. While winter boiler energy usage is substantially reduced for a building in an urban location with a low proportion (approximately 3\%) of greenspace, the wintertime benefit is marginal when analysed in terms of carbon trade-offs between summer cooling and winter heating requirements.

\section{References}

Akbari $\mathrm{H}$., 2002: Shade trees reduce building energy use and $\mathrm{CO}_{2}$ emissions from power plants. Environmental Pollution, 116 (Supplement 1), S119-S126

Ali-Toudert F., Mayer H., 2006: Numerical study on the effects of aspect ratio and orientation of an urban street canyon on outdoor thermal comfort in hot and dry climate. Building and Environment, 41 (2), 94-108

Arnfield A. J., 2000: A simple model of urban canyon energy budget and its validation. Physical Geography, 21, 305-326

Baklanov A., Grimmond C.S.B., Mahura A., Athanassiadou M., Eds., 2009: Meteorological and Air Quality Models for Urban Areas. Berlin Heidelberg: Springer-Verlag

Bruse M. 2004: ENVI-met 3.0: Updated Model Overview, http://www.envi-met.com/documents/papers/overview30.pdf Accessed 15 May 2015.

Bruse M., Fleer H., 1998: Simulating surface-plant-air interactions inside urban environments with a three dimensional numerical model. Environmental Modelling and Software, 13 (3-4), 373-384

Cheung H. K. W., 2011: An Urban Heat Island Study for Building and Urban Design. School of Mechanical, Aerospace and Civil Engineering, Manchester, University of Manchester, PhD: 273.

CIBSE 2000: Energy consumption guide 19: Energy use in offices. Energy Efficiency Best Practice Programme. London, Crown copyright

HM Government, 2002: Building and Buildings, England and Wales. The Building (Amendment) Regulations 2002. England and Wales, The Stationery Office Limited

HM Government, 2010: L2A Conservation of Fuel and Power in New Buildings Other Than Dwellings. London, HM Government.

Levermore G., Parkinson J., 2014: The Manchester Urban Heat Island and Adjustments for CIBSE Calculations. CIBSE ASHRAE Technical Symposium, 3-4 April 2014, Dublin, Ireland

Lim M. C. N., 2009: UK Building Energy Software Approval Scheme. Eleventh International IBPSA Conference, 27-30 July 2009, Glasgow, Scotland

Skelhorn C., 2013: A Fine Scale Assessment of Urban Greenspace Impacts on Microclimate and Building Energy in Manchester. School of Environment, Education, and Development, Manchester, University of Manchester, PhD: 198.

Skelhorn C. P., Lindley S.J., Levermore G., 2014a: The impact of vegetation types on air and surface temperatures in a temperate city: A fine scale assessment in Manchester, UK. Landscape and Urban Planning, 121, 129-140.

Skelhorn C. P., Lindley S.J., Levermore G., 2014b: Impacts on Cooling Energy Consumption Due to the UHI and Vegetation Changes in Manchester, UK. Third International Conference on Countermeasures to Urban Heat Island, 13-15 October 2014, Venice, Italy

Steadman P., Bruhns H. R., Gakovic B., 2000: Inferences about Built Form, Construction, and Fabric in the Nondomestic Building Stock of England and Wales. Environment and Planning B: Planning and Design 27 (5): 733-758. 